should be assessed in its context, with reference to the other introductory courses offered at its department at the same time.

Drawing on these four approaches, I would like to offer the following suggestions about how to teach an introductory course of international relations in the early 1990s. In my view, the recipe for such a course should include $13 \%$ of the lectures (about three) on international law and international organizations (international organizations, international law, and world order, the evolving role of the United Nations); $13 \%$ of the lectures (about three) on methodology (traditional and scientific approaches, levels-of-analysis problem, philosophies and paradigms in international relations); $37 \%$ of the lectures (about nine) on international security and peace studies (including some historical background if it is not provided in a parallel course); and 37\% (about nine) of the lectures on international political economy and global issues. Furthermore, the approach should be eclectic, to the extent that the lectures should emphasize theoretical issues, while the discussion groups should debate historical and contemporary issues, in an effort to apply the basic concepts and theoretical tools learned in the lectures. In my opinion, a clear distinction should be established between international relations per se and foreign policy, and between levels of analysis and paradigmatic/philosophical approaches to international relations. Finally, international political economy and other global issues should get at least the same weight as the more traditional discussions of peace and war. To establish a logical link or thread among the different subjects and themes, two strategies might be followed: either through the different levels of analysis (first, second, and third images of international relations), or through the different philosophies or world-views of international relations (Realism, Liberalism, and Marxism). In this fashion, the instructor should also keep track of the contemporary changes in international relations, the globalization of international relations, and the integration of security and international economic studies. After all, the "menu for choice" of world politics is not restricted to the selection of the decision makers only. Since we bear the heavy responsibility of introducing our students to the academic world of international relations, we are entitled to choose as well, with the hope that our world resembles the real one sufficiently that it is also capable of affecting reality in a constructive way.

\section{Note}

*I would like to thank Yaacov Y. I. Vertzberger from the Hebrew University of Jerusalem, Steve Walt from the University of Chicago, Roy Licklider from Rutgers University, and Barbara Farnham from Columbia University for allowing me to use their course materials. I am grateful to Sammy Basu, Jacques Bertrand, and Roy Licklider for their comments and suggestions on a preliminary draft of this paper.

\section{References}

Jervis, R. 1991. "The Future of World Politics: Will It Resemble the Past?" International Security 16: 39-73.

Rosenau, J. N. 1990. Turbulence in World Politics: $A$ Theory of Change and Continuity. Princeton, NJ: Princeton University Press.

\section{About the Author}

Arie M. Kacowicz is an instructor, department of international relations, Hebrew University of Jerusalem. He obtained his Ph.D. from Princeton University in June 1992. His dissertation is entitled "Peaceful Territorial Change."

\title{
Easing the Transition: From Doctoral Student to Academic Professional
}

\author{
Beth M. Henschen, Loyola University of Chicago
}

While it is increasingly being recognized that most doctoral students receive little or no training to prepare them for assuming the role of faculty member, few graduate institutions have undertaken comprehensive programs designed to prepare tomorrow's professoriate. Typically, graduate education focuses on developing a student's substantive specialization and assumes that teaching competence and a sense of professionalism come with the awarding of the Ph.D. degree.
At Loyola University of Chicago, the graduate school has taken seriously the need to prepare doctoral students for the many roles they will play as academic professionals: teacher, researcher, departmental and institutional "citizen." Each year, 22 advanced doctoral students from nine departments are chosen on a competitive basis to participate in the Teaching Fellows Program. Fellows teach four courses (introductory and upper-level) during the year and attend weekly seminars that address issues of classroom effectiveness, research and publication, and professional obligation. Administrators and faculty members from a variety of disciplines speak to the fellows on topics such as strategies for leading classroom discussion, the art of lecturing, understanding the undergraduate, teaching critical thinking, presenting conference papers and publishing journal articles, writing grant proposals, the academic job interview process, legal issues confronting faculty, and ethical dimensions of the 
academic profession. On an informal basis, the fellows also share with one another their experiences in the classroom and the techniques they have found most useful in helping their own students learn.

The Teaching Fellows Program is directed by a faculty member who develops the seminar series and who serves as a teaching resource and sounding board for the fellows. Each teaching fellow is also assigned a faculty mentor in his or her own academic department. These faculty members provide help with discipline-specific concerns, review course syllabi, and offer suggestions on text selection. They also observe their fellows in the classroom several times a year and offer constructive feed- back. Thus while the weekly seminars provide a forum for an interdisciplinary exchange of ideas and discussion of topics relevant to everyone pursuing an academic career, fellows also have role models who offer advice on teaching as well as research in their own disciplines and who contribute to their professional development.

Established in 1988, Loyola's Teaching Fellows Program eases the transition from student to professional. Though it is interdisciplinary, the program's format could easily be adapted within a single department and many of its most important virtues would remain. These future professors have significant teaching experience with considerable mentor- ing, and they begin their academic careers already knowing what many faculty members often find out too late.

\section{Two New Units from the Choices Education Project}

\section{U.S. Immigration Policy in an Unsettled World 52 pages/reproducible Grades 9-12, \$8.00 per unit}

The United States is a nation of immigrants. Many Americans have questioned the values underlying the laws that decide who may now become an American. This one-week unit calls on students to examine the many facets of an issue that is fast becoming a key focus of U.S. foreign policy and has fueled the ongoing debate about our national identity.
Coming to Terms with Power: U.S. Choices After World War II 62 pages/reproducible

Grades $9-12, \$ 8.00$ per unit

The conclusion of World War II left the United States as the most powerful nation on earth, and yet the country was uneasy with its sudden prominence in world affairs. This one-week unit engages students in the national debate on the U.S. role in the world that gripped the United States in 1946-47. Students will explore the range of choices that challenged the country at one of its most critical historical junctures.

For further information: Center for Foreign Policy Development, Thomas J. Watson Jr., Institute for International Studies, Brown University, Box 1948, Providence, RI 02912. Phone: (401) 863-3465. Fax: (401) 274-8440.

\section{Asia in the Core Curriculum}

The 1980s witnessed the growing recognition on U.S. campuses of the importance of increasing education about Asia at the undergraduate level in order to prepare American students who will lead the nation in the
21 st century, often called "the century of the Pacific." Considering that six of the ten most populous countries in the world lie in Asia, that the world's fastest growing economies are in Asia, and that U.S. trade across the Pacific is double the trade across the Atlantic, the importance of Asia to America can only grow.

As many institutions sought ways to incorporate Asian content into the 
general education curriculum, the Project on Asia in the Core Curriculum-involving over 100 scholars, Asianists and non-Asianists, from 75 undergraduate institutions of different sizes and types-was inaugurated in 1984 under the leadership of Columbia University to facilitate dialogue on materials and approaches. This national effort has been supported by the National Endowment for the Humanities, the Luce Foundation, the Matsushita Foundation, and the U.S. Department of Education.

The project has produced three books-Asia: Case Studies in the Social Sciences, A Guide for Teaching (December 1992), Masterworks of Asian Literature in Comparative Perspective: $A$ Guide for Teaching (to be published in 1993), and Asia in Western and World History: $A$ Guide for Teaching (to be published in 1994). All three guides are being published and distributed by M.E. Sharpe, Inc., Armonk, New York. The guides identify themes, texts, and comparative concepts that provide avenues of entry for Asian content into core courses. Each guide contains 40 or more clear and succinctly written essays. A logical, detailed format provides teachers with multiple approaches to the material. Following each essay are suggested topics for discussion and selected readings.

Of particular interest to political scientists is the guide devoted to case studies in the social sciences, edited by Myron L. Cohen. The guide features case studies on China, India,
Pakistan, Indonesia, Japan, Taiwan, Korea, Thailand, Vietnam, and the Philippines for introductory courses in anthropology, economics, political science, and sociology. In his introduction, Professor Cohen sets forth the rationale for a case study approach:

Except in terms of a disciplinary or topical focus, there can be no textbook on all of Asia united by a theme other than geography. Such a circumstance makes the case-study approach employed in this book all the more appropriate for an instructor seeking to expose students to such an important part of the world. ... Within the limits posed by restriction to one volume the attempt has been made to have the different social science disciplines as well as Asia's cultural and social diversity reasonably well represented. The case-study format [provides] treatment of particular subjects in sufficient detail to enable their inclusion in classroom lectures without requiring additional background preparation by the instructor.

To facilitate the adaptation of the cases for classroom use, each essay begins with a list of the topics covered and an overview of central theoretical points that can be included in lectures. The remainder of the essay elaborates these central points and concludes with a list of suggested "Issues for Discussion" to be raised with students. The . "Selected Readings" at the end of each essay include both books and articles appropriate for a course syllabus and those recommended for further faculty reference.
A political scientist wanting material for courses on political parties or behavior, for example, will find cases for China, India, Japan, or the Philippines. Political scientists who want to focus on a single country will find very readily useful material. For instance, under "Political Science: Japan," there are case studies of bureaucracy, political culture, and political parties and representation while under "Political Science: Southeast Asia," the choice includes political development in Thailand, authoritarianism in Indonesia, political culture in Indonesia, political parties and representation in the Philippines, and the military in Indonesia.

Each entry is a discrete essay, but entries for several disciplines on any given country provide complementary approaches to the same society. The reader may wish to peruse them all in order to gain a better understanding of that society. A course which includes comparison of two or more different Asian cases of "religion in society," "the family," or "military in politics" will offer to students an appreciation of the variety of Asian cultures within the controlled context of a particular issue.

Asia: Case Studies in the Social Sciences, A Guide for Teaching, 656 pages, $\$ 60.00$ hardcover, $\$ 17.95$ paperback, is available now directly from the publisher or through a local bookstore. For more information on this and the two companion guides contact the publisher, M.E. Sharpe, Inc., 80 Business Park Drive, Armonk, NY 10504. Phone: (914) 273-1800. Fax: (914) 273-2106. 